\section{All tied up in knots}

\author{
Tim Davies, Alice Man
}

North Middlesex Hospital London, UK

\section{Correspondence to}

Dr Tim Davies,

tjd@doctors.org.uk

To cite: Davies T, Man A. BMJ Case Reports Published online: [please include Day Month Year] doi:10.1136/ bcr-2012-007822

\section{DESCRIPTION}

A 42-year-old woman was scheduled for a laparoscopic cholecystectomy. She was American Society of Anesthesiologists grade 1 and had no obvious anomalies of the airway, Mallampatti score was 2 .

After induction, laryngoscopy revealed a Cormack and Lehane grade II view. Intubation was with a size 8.0 cuffed tracheal tube (TT). A lubricated 22F, $78 \mathrm{~cm}$ orogastric tube (OGT) was then inserted blindly with minimal resistance to $55 \mathrm{~cm}$. Suction was applied, producing a small amount of thin yellow secretions; a bile bag was then attached.

The surgeons commented that the stomach was adequately deflated however no gastric contents were evident in the bile bag.

At the end of the operation the OGT was suctioned and initially met no resistance upon removal. At half way mild resistance was felt. At approximately $20 \mathrm{~cm}$ there was a sudden increase in resistance, even gentle traction on the OGT created movement of the TT. We decided to leave the partially removed OGT tube in place as no ventilatory compromise was evident.

The patient was extubated, removing what is shown in figure 1.

We theorise that the OGT looped around the TT on insertion and formed a loose knot in the mouth that did not impede advancement into the oesophagus. Upon removal, the tension applied caused the knot to be drawn further down the OGT and tighten around the TT.

There have been reports of gastric tubes becoming knotted around the TT. ${ }^{1-3}$ There is a common theme in each case: all were passed blind and had difficulty in placing the gastric tube.

\section{Learning points}

Even gastric tubes that meet no or minimal resistance when passed blind have the potential for knotting or misplacement.

- Place gastric tubes under direct vision to avoid looping in oropharynx in anaesthetised patients.

- If any resistance is felt upon removal of gastric tube have a high index of suspicion for knotting to the TT because continued attempt at extraction could cause unintentional extubation ${ }^{3}$ with respiratory compromise or larnygospasm.

\section{Patient consent Obtained.}

Competing interests None.

Provenance and peer review Not commissioned; externally peer reviewed.

\section{REFERENCES}

1 Dorsey M, Schwinder L, Benumof JL. Unintentional endotracheal extubation by orogastric tube removal. Anesth Rev 1988;15:30-3.

2 Au-Truong X, Lopez $G$, Joseph NJ, et al. A case of a nasogastric tube knotting around a tracheal tube: detection and management. Anesth Analg 1999;89:1583-4.

3 Young MJ, Ehrenfeld JM. Knotting of an orogastric tube around an endotracheal tube. J Clin Anesth 2012;24:254-5.
Figure 1 The orogastic tube is clearly knotted around the tracheal tube, however the lumen of the tracheal tube is left patent.
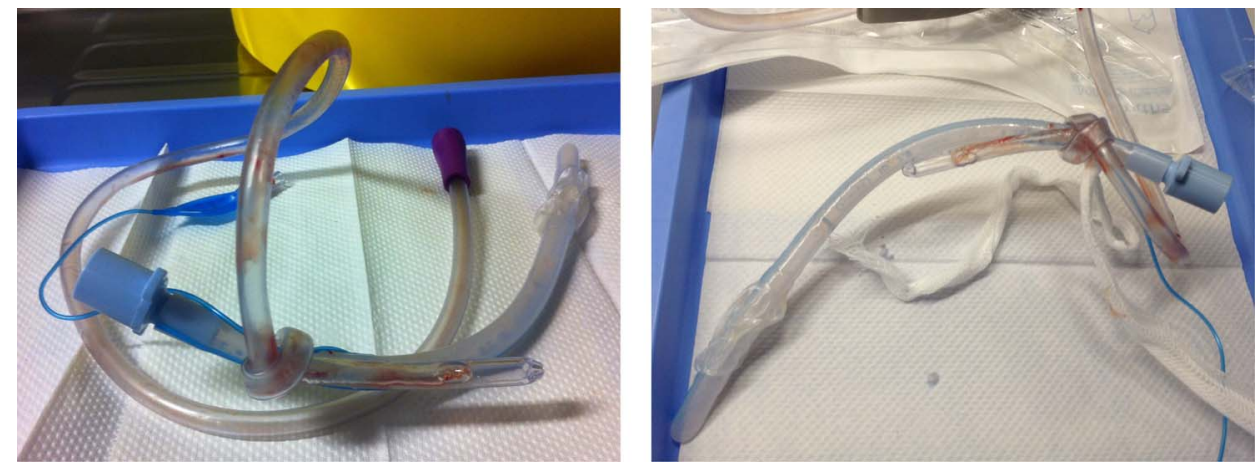
Copyright 2013 BMJ Publishing Group. All rights reserved. For permission to reuse any of this content visit http://group.bmj.com/group/rights-licensing/permissions.

BMJ Case Report Fellows may re-use this article for personal use and teaching without any further permission.

Become a Fellow of BMJ Case Reports today and you can:

- Submit as many cases as you like

- Enjoy fast sympathetic peer review and rapid publication of accepted articles

- Access all the published articles

- Re-use any of the published material for personal use and teaching without further permission

For information on Institutional Fellowships contact consortiasales@bmjgroup.com

Visit casereports.bmj.com for more articles like this and to become a Fellow 